\title{
Spatial Differentiation and Market Potential of the Regions: the Case of Russia
}

\author{
Tatiana Miroliubova $^{1} \&$ Alexander Biryukov ${ }^{2}$ \\ ${ }^{1}$ Department of Economics, Perm State National Research University, Perm, Russian Federation \\ 2 Department of Economic Theory and Analysis, Bashkir State University, Sterlitamak, Republic of \\ Bashkortostan, Russian Federation \\ Correspondence: Tatiana Miroliubova, Department of Economics, Perm State National Research University, \\ 614990 Perm, Bukireva str. 15, Russian Federation. E-mail: mirolubov@list.ru
}

Received: September 22014 Accepted: October 18, 2014 Online Published: April 2, 2015

doi:10.5539/ass.v11n9p96

URL: http://dx.doi.org/10.5539/ass.v11n9p96

\begin{abstract}
This paper investigates spatial differentiation between Russian regions in the context of business location factors. First, we selected a number of variables to describe key factors of business location in the regions. They include market potential of the region's retail markets, fixed asset investments, the number of economically active population, and average nominal monthly wage in the region. Segmentation of Russian regions on the basis of these variables allows comparison and selection of the regions from investors' standpoint. To segment Russian regions on the basis of the selected variables we use self-learning neural networks allowing assessment of several variables with the lack of some input data. Second, we classified Russian regions based on their market potential indicators and represented the results on the map of Russia. We presented a structure of Russian regions which accounts for spatial differentiation of the market potential.
\end{abstract}

Keywords: spatial differentiation, factors of business location, market potential, Kohonen's self-organizing maps, Russian regions

\section{Introduction}

Russia has been transforming into a market economy since the early 1990-s. These changes have had different impacts on the socio-economic development of Russian regions. Some of them have successfully adjusted to new conditions and are experiencing economic growth and gain in living standards. Other regions still suffer economic stagnation and decline in their living standards.

As a result modern Russia is characterized by increased spatial differentiation and regional inequalities. This leads to such problems as economic slowdown, considerable outflow of population from unsuccessful regions to successful ones, growing separatist sentiment, disintegration processes, etc. To solve these problems we need to study spatial differentiation in modern Russia, to determine its features and sources. The results of this study can provide the basis for an effective economic policy both at the federal and regional levels.

Economic heterogeneity of territories, characteristic of the modern world, is an integral part of the economic area and the result of regional diversity. Spatial differentiation of economic development is an objective reality that exists both between countries and regions within one country. This is especially true for countries with a large area. The study of spatial differentiation in Russia's economic development has become very acute, as Russia is the world's largest country by area.

A lot of works within the framework of new economic geography have been devoted to the theoretical analysis of spatial economic development (Krugman, 1991; Matsuyama, 1991; Venables, 1996; Fujita et al., 1998; Krugman \& Venables, 1995, 1996; Puga, 1999; Martin \& Ottaviano, 1996, 1999; Baldwin, 1998; Markusen \& Venables, 1997; Baldwin et al., 2003). Their conceptions are based on the Dixit-Stiglitz model of monopolistic competition (Dixit \& Stiglitz, 1977).

In conditions of imperfect competition firms' decisions on geographical (territorial) location of a business are becoming particularly important. Under otherwise equal conditions firms, trying to reduce transport costs, choose locations closer to major markets with high potential demand for their products. Market potential plays a key role in the investor's decision making about locating production in this or that region. 
Market potential (Harris, 1954) characterizes the level of regional market accessibility to businesses, consumers and other economic agents. Harris found out that, on the one hand, some industrialized regions of the USA had extremely high market potential. But on the other hand, not only regions with good market access were chosen for production location; concentration of production also improved access to the market. On this basis C. Harris deduced that market potential of a region is the main factor in production location.

According to the Keynesian approach to economic development, the relationship between economic growth and investment is explained with the help of Harrod-Domar model (Harrod, 1939; Domar, 1946). Central to the model is positive correlation between the rate of investment and economic growth.

If a decision on business location and investment in a region is made by a firm, but not by the state, the level of the economic development of the region will depend on the business investment. This is the principal difference between the market economy of modern Russia and the command-administrative socialist economy. Under socialism all production location decisions in Russia were made centrally by the State Planning Commission, a special state body.

Choosing a region to invest in, the investor will compare regions on a number of parameters. This requires selection of Russian regions where a business can achieve maximum return on investment.

In order to do this, it is necessary to segment all Russian regions in groups according to several features. To evaluate a region from different perspectives, it is necessary to conduct comparative analysis of regional economies based on a number of features. It should be emphasized, that one or two features are not enough and a thorough analysis can require three, four or even more features. Thus, application of the multivariate analysis methods, allowing simultaneous use of several variables to segment selected objects, is needed for research.

Segmentation allows to select regions with similar characteristics for the analysis and to solve several problems. Firstly, investors can compare and select regions more accurately. First of all, it is necessary to group all the regions, select the most attractive group of regions and then compare different regions within each group depending on the investor requirements for natural and labor resources, tax, infrastructure, etc. This will allow to select the most attractive regions.

Secondly, this can help the government bodies of regions within one group set clear goals and performance measures to create strategies of socio-economic development of the regions, as these particular regions, which are very similar and members of one group, have to compete with each other for capital resources.

Our research has the following objectives:

- create a set of indicators (factors) $\left\{X_{j}\right\}$, representing regional specific features for investors and their transformation in one composite index $\mathrm{F}(\mathrm{X})$, where $\mathrm{X}=\left(X, . ., X_{j}, \ldots X_{n}\right)$, all of them should account for the regional specificity of the clustering model;

- apply the clustering model of Russian regions to the neural network using Kohonen's self-organizing maps;

- to conduct empirical analysis using real statistics for Russia's regions in order to test the hypotheses put forward in this study.

In our research we intend to test the following hypotheses:

1) according to the systemic analysis, assessment of a region in terms of business location should be systemic, but not for each individual region. This means that it is necessary to compare parameters of the analyzed region with other regions.

2) business location in Russian regions depends on its market potential, the number of economically active population, and the average nominal monthly wage. A quantitative indicator characterizing a region is the volume of fixed asset investments.

3) Russia's economy is characterized by spatial differentiation of business locations in the regions.

4) Russian regions are characterized by spatial differentiation of the retail market potential.

This research aims at contributing to the study of spatial differentiation between Russian regions and conducting empirical estimation of market potential and other factors of business location in Russian regions. We use self-learning neural networks which allow assessment of several variables with the lack of some input data. The research will result in a structure of Russian regions accounting for special differentiation of market potential as well as other business location factors. 


\section{Methodology and Data}

\subsection{Key Characteristics of a Region}

A business, investing into production of goods in a region, wants to maximize its profit. Therefore, the business is particularly interested in the quantity demanded of the product in this and nearby regions as well as in those regions, transportation costs to which and the price level of which allow profit.

In our research we apply Harris's formula (Harris, 1954) defining the market potential of a region as the inverse distance-weighted sum of the purchasing power of all regions:

where:

$$
\mathrm{MP}_{\mathrm{i}}=\Sigma\left(\frac{M j}{D i j}\right)
$$

$$
\begin{aligned}
& \mathrm{MP}_{\mathrm{i}} \text { is the market potential of county } i \text {; } \\
& M j \text { is the market of county } j \text {; } \\
& M i j \text { is the distance from county } i \text { to county } j \text {. }
\end{aligned}
$$

To make necessary calculations with the help of this formula, it is crucial to select empirical data: what data to use in the calculation?

Let us refer to the first necessary variable - the market size of a region.

According to the classical macroeconomic approach, the market size can be calculated by the value of sales to a market in a given period. It is based on the assumption that theoretically any Russian region can be a potential market for other regions of the country.

In the calculations we will use the retail turnover indicator for Russian regions in 2005 and 2010. Our information source is the Central statistical database of the Federal State Statistics Service of the Russian Federation. In this case we will be able to assess the regional market potential from a consumer demand perspective.

Retail markets, with total sales of 635833 million dollars (19075 billion rubles) and 2436.6 thousand people in 2011, are an important part of Russia's economy. 57\% of goods sold at these markets are produced in Russia and $43 \%$ of goods are imported (Russia-2012, pp. 33-34). These particular markets allow producers to sell their products.

The main problem with calculating the market potential of Russian regions is the lack and poor quality of information, or incompleteness of information. Another limitation for this research is that the Federal State Statistics Service of the Russian Federation can not provide information on all indicators or all 83 Russian regions. To overcome this limitation we need to select appropriate research methods.

A second variable needed for the calculation is the distance between the region under consideration and other regions of the country.

To assess the market potential of a region we will use the shortest railway route between the administrative center of the region under consideration and those of other regions of the country. For regions with no train service modified data on driving, river and sea distances will be used. Thus, we will use not just a geographical straight line distance, but a so called "economic" distance, which depends on economic people's activities including availability of road/rail/sea/ river transport links. The information on distances between the main cities of Russian regions is taken from calculations of Russian scientists (Abramov \& Gluschenko, 2000).

Besides the market potential, we will need some other parameters characterizing the regions.

In modern economy an investor first of all needs qualified workforce to build a globally competitive business. A business should be able to recruit personnel with good job skills. That is why such a characteristic of regional economy as "the number of economically active population" is very important for an investor.

From an investor's perspective, to maximize profit it is necessary to evaluate factors affecting the production costs. It is important to know the cost of labor in the region, which is characterized by the average monthly nominal wage index.

To make the right choice an investor should also know the general economic activity of business in the region. Therefore, we will use such an indicator as "fixed assets investment" in the region.

Thus, for our research we have selected the following variables: market potential of a region, fixed asset investment, economically active population, and average monthly nominal wages in a region. 
Information on the variables is taken from the Central statistical database of the Federal State Statistics Service of the Russian Federation for the years 2005 and 2010.

\subsection{Neural Network Approach to Data Classification}

Studies on spatial differentiation generally use traditional methods of econometric modeling. As it has been stated, we will do our research with incomplete information. Thus, to overcome this limitation we will use artificial neural networks. They can be more effective than traditional research methods. Compared to traditional methods, the main advantage of the artificial neural networks is that they are not programmed but trained.

Theoretical and practical aspects of using artificial neural networks are discussed in many scientific works.

McCulloch W. S., Pitts W. in their work (McCulloch \& Pitts, 1943) first suggested a mathematical model of the biological neural network, and later Hebb D. O. (1949) formulated basic rules of learning a neural network.

Rosenblatt F. (1958) was one of the first to suggest a mathematical representation of the living neuron to recognize data patterns. He also conducted a series of experiments proving the possibility of such applications.

Minsky M. L. and Papert S. A. (1969) conducted a detailed mathematical analysis of Rosenblatt perceptron properties and, in particular, proved that existing learning algorithms do not allow the use of perceptron to solve n-separable problems. This work significantly declined interest in artificial neural networks for more than a decade.

Rumelhart D. E., Hinton G. E. and Williams R. J. (1986) suggested a method for training artificial neural networks with a nonlinear activation function and a hidden layer, which solved the issue of n-separable problems and renewed interest in artificial neural networks.

Kohonen T. (1982) suggested a structure of the neural network capable of self-learning through clustering the input data space. It is T. Kohonen's work that initiated a widespread use of artificial neural networks in scientific research.

Hopfield J. J. (1982) developed a fundamentally new architecture of the artificial neural network with self-feedback (recurrent network). Unlike previous artificial neural networks, Hopfield recurrent networks are models of physical, not biological processes allowing to solve problems using associative memory.

Haykin S. (1999) summarized about 1200 most important works on neural network theory. His work is still considered the most comprehensive study in the field of neural network modeling.

Using neural networks allows a principally new level of creating algorithms to solve many complex problems with incomplete information, which is especially important for solving economic problems. Economic, financial and social systems result from actions and reactions of both objective reality and individuals. This makes it difficult to create a complete mathematical model with account for all possible actions and reactions. It is almost impossible to get a detailed approximation of the model based on such traditional parameters as utility and profit maximization.

Models directly imitating social and economic behavior are more effective to use in such complex systems. This is what the neural network methodology allows to do.

In this study we suggest segmentation of the regions on the basis of the market potential and other selected parameters using the Kohonen layer and Kohonen's self-organizing networks (sometimes called maps) (Kohonen, 1982).

According to different authors, Kohonen's neural networks, or Kohonen's self-organizing maps (SOM), are used for automated classification with no training sequence of patterns, i.e. when there is no a priori information of the desired output (Kruglov \& Borisov, 2001). Consequently, there is no knowledge of the error between the network's and some desired outputs and no need to minimize this error like in the back propagation algorithm.

Using Kohonen's self-organizing maps - one of the neural network algorithms - for analysis allows the automation of pattern discovery.

The main advantage of this method is that the result of the training process depends only on the input data structure. In this method an artificial network of connected neurons during its unsupervised training process tries to understand the relationship between input data and to visualize it on the map.

In this research we used the following methodology. First, we figured out the factors characterizing regional economy from different perspectives. These factors affect the location of a business in Russian regions and include market potential of a region, fixed asset investment, economically active population, and average monthly nominal wage in a region. 
Second, we calculated retail market potential for Russian regions using Harris's equation. We also formed generalized indicator $F\left(X_{J}\right)$ based on the selected factors and created generalized production function $F(\vec{X}(t), t)$ using Zwicky's morphological approach (see: Odrin \& Kartavov, 1977). Zwicky suggested the idea of defining additive sets of values (conditions), shown at the axes of the morphological box, and "reducing" all mutually contradictory conditions with the help of the cross-consistency assessment. Specifically, in our task of clustering Russian regions the main useful function $\mathrm{F}((\mathrm{t}), \mathrm{t})$ is written as:

$$
F(\vec{X}, t)=F_{1}(\vec{X}, t) \cdot F_{2}(\vec{X}, t) \cdot F_{3}(\vec{X}, t) \cdot F_{4}(\vec{X}, t),
$$

where $t$ is the time; $F_{I}(\vec{X}, t)$ is the indicator of a region's market potential; $F_{2}(\vec{X}, t)$ is the indicator of fixed asset investments; $\mathrm{F}_{3}(\vec{X}, t)$ is the indicator of the number of economically active population; and $\mathrm{F}_{4}(\vec{X}, t)$ is the indicator of the average nominal monthly wage in the region.

Multiplication of partial criteria $\left\{F_{k}\right\}$ in (2) represents the interrelationship of all indicators in the overall assessment $\mathrm{F}$ of a region: this indicator will reach its maximum value in case of simultaneously maximum values of all aggregates $F_{l}, \ldots F_{p}$.

To explore causal relationship between the selected factors of business location in Russian regions, we carried out correlation and regression analysis. It was found out that a quantitative indicator characterizing the location of a business is fixed asset investment in a region.

Next, we use Kohonen's method of self-organizing maps to calculate the selected factors across Russian regions. After that we rate the regions based on the selected indicators, sum up rating positions for every region and classify the regions.

Finally, we classify Russian regions based on the market potential of their retail markets.

\section{Calculation Results}

\subsection{Spatial Differentiation of Market Potential in Russian Regions}

Retail market potential in Russian regions was calculated based on the above mentioned methodology. Retail trade turnover across Russian regions from 2005 to 2010 was chosen as input data. The central statistical database of the Federal State Statistics Service was chosen as the source of information. Another indicator used for the calculation was the shortest railway between the administrative centre of the region under consideration and other regions.

The results of the calculation of market potential for Russian regions in 2005 and 2010 are given in Table 1.

Table 1. Market potential of Russian regions (across retail markets)

\begin{tabular}{|c|c|c|c|}
\hline Subject of the RF & Administrative center & 2005 & 2010 \\
\hline Belgorod Oblast & Belgorod & 9556,54 & 16213,29 \\
\hline Bryansk Oblast & Bryansk & 12737,3 & 20912,07 \\
\hline Vladimir Oblast & Vladimir & 20725,56 & 33215,92 \\
\hline Voronezh Oblast & Voronezh & 11668,5 & 19827,63 \\
\hline Ivanovo Oblast & Ivanovo & 16134,2 & 26435,47 \\
\hline Kaluga Oblast & Kaluga & 21042,77 & 33629,99 \\
\hline Kostroma Oblast & Kostroma & 14849,04 & 24462,92 \\
\hline Kursk oblast & Kursk & 11159,82 & 18829,39 \\
\hline Lipetsk Oblast & Lipetsk & 13379,11 & 22371,65 \\
\hline \multicolumn{2}{|c|}{ Moscow } & 28605,01 & 53282,77 \\
\hline Moscow oblast & Krasnogorsk & 96288,87 & 138294,28 \\
\hline Orlov Oblast & Orel & 13868,06 & 22980,86 \\
\hline Ryazan Oblast & Ryazan & 20400,17 & 32634,79 \\
\hline Smolensk Oblast & Smolensk & 12007,03 & 19641,63 \\
\hline Tambov Oblast & Tambov & 12822,67 & 21524,79 \\
\hline Tver Oblast & Tver & 22014,98 & 34879,38 \\
\hline Tula Oblast & Tula & 21361,93 & 34011,31 \\
\hline Yaroslavl Oblast & Yaroslavl & 16681,06 & 26984,95 \\
\hline Arkhangelsk Oblast & Arkhangelsk & 5620,66 & 9515,3 \\
\hline Vologda Oblast & Vologda & 11396,72 & 18846,63 \\
\hline Kaliningrad Oblast & Kaliningrad & 5169,76 & 8714,21 \\
\hline
\end{tabular}




\begin{tabular}{|c|c|c|c|}
\hline Subject of the RF & Administrative center & 2005 & 2010 \\
\hline Republic of Kareliya & Petrozavodsk & 7121,04 & 11999,9 \\
\hline Komi Republic & Syktyvkar & 10055,86 & 10735,51 \\
\hline Leningrad Oblast & Gatchina & 12181,62 & 21749,09 \\
\hline Murmansk Oblast & Murmansk & 3959,94 & 6729,2 \\
\hline Nenets Autonomous Okrug & Naryan-Mar & 2962,55 & 5068,64 \\
\hline Novgorod Oblast & Veliky Novgorod & 11657,59 & 19242,07 \\
\hline Pskov Oblast & Pskov & 8985,06 & 14985,42 \\
\hline Saint-Petersburg & & 9810,83 & 16611,34 \\
\hline Republic of Adygeya & Maikop & 7305,93 & 15499,47 \\
\hline Astrakhan Oblast & Astrakhan & 6213,36 & 11021,25 \\
\hline Volgograd Oblast & Волгоград & 8044,42 & 14289,65 \\
\hline Kalmykia & Elista & 7618,19 & 13741,54 \\
\hline Krasnodar Krai & Krasnodar & 6733,23 & 11419,34 \\
\hline Rostov Oblast & Rostov-on-Don & 7213,25 & 13527,84 \\
\hline Republic of Daghestan & Makhachkala & 5012,89 & 9010,09 \\
\hline Ingush Republic & Magas & 6785,55 & 12653,21 \\
\hline Kabarda-Balkar Republic & Nalchik & 6256,9 & 11627,94 \\
\hline Karachai-Cherkes Republic & Cherkessk & 7385,94 & 13798,48 \\
\hline Republic of North Ossetia - Alania & Vladikavkaz & 6071,59 & 11320,24 \\
\hline Stavropol Krai & Stavropol & 6663,91 & 12547,52 \\
\hline The Chechen Republic & Grozny & 6045,21 & 11256,22 \\
\hline Republic of Bashkortostan & Ufa & 8001,02 & 14042,53 \\
\hline Kirov Oblast & Kirov & 8780,56 & 15257,94 \\
\hline Republic of Mari El & Yoshkar-Ola & 11203,48 & 19340,53 \\
\hline Republic of Mordovia & Saransk & 11250,9 & 19255,25 \\
\hline Nyzhniy Novgorod Oblast & Nyzhniy Novgorod & 12414,56 & 20770,28 \\
\hline Orenburg Oblast & Orenburg & 12385,03 & 12578,36 \\
\hline Penza Oblast & Penza & 11152,67 & 18927,08 \\
\hline Perm Krai & Perm & 7943,13 & 14239,7 \\
\hline Samara Oblast & samara & 8351,68 & 14730,65 \\
\hline Saratov Oblast & Saratov & 9471,22 & 16310,02 \\
\hline Republic of Tatarstan & Kazan & 10109,97 & 17453,66 \\
\hline Republic of Udmurtiya & Izhevsk & 8604,84 & 14819,23 \\
\hline Ulyanovsk Oblast & Ulyanovsk & 10556,82 & 18200,19 \\
\hline Republic of Chuvashia & Cheboksary & 11761,70 & 20295,48 \\
\hline Kurgan Oblast & Kurgan & 7891,99 & 13827,73 \\
\hline Sverdlov Oblast & Ekaterinburg & 7614,25 & 13423,27 \\
\hline Tyumen Oblast & Tyumen & 6301,72 & 11092,14 \\
\hline $\begin{array}{c}\text { Khanty-Mansi Autonomous Okrug } \\
- \text { Yugra }\end{array}$ & Khanty-Mansiysk & 3676,5 & 6384,37 \\
\hline Chelyabinsk Oblast & Chelyabinsk & 7932,14 & 14009,34 \\
\hline Altai Republic & Gorno-Altaisk & 4117,20 & 6996,31 \\
\hline Altai Krai & Barnaul & 4549,30 & 7687,91 \\
\hline Republic of Buryatia & Ulan-Ude & 2470,17 & 4185,81 \\
\hline Trans-Baikal Krai & Chita & 2046,63 & 3492,3 \\
\hline Irkutsk Oblast & Irkutsk & 2489,15 & 4273,89 \\
\hline Kemerovo Oblast & Kemerovo & 4639,63 & 8214,47 \\
\hline Krasnoyarsk Krai & Krasnoyarsk & 3411,88 & 5792,6 \\
\hline Novosibirsk Oblast & Novosibirsk & 4909,79 & 8321,87 \\
\hline Omsk Oblast & Omsk & 5043,87 & 8732,45 \\
\hline Tomsk Oblast & Tomsk & 5022,46 & 8471,95 \\
\hline Republic of Tyva & Kyzyl & 2888,14 & 4938,67 \\
\hline Republic of Khakassia & Abakan & 3569,80 & 6081,1 \\
\hline Amur Oblast & Blagoveshchensk & 1695,48 & 2886,84 \\
\hline Jewish Autonomous Region & Birobidzhan & 2124,59 & 3542,96 \\
\hline
\end{tabular}




\begin{tabular}{cccc}
\hline Subject of the RF & Administrative center & $\mathbf{2 0 0 5}$ & $\mathbf{2 0 1 0}$ \\
\hline Magadan Oblast & Magadan & 1135,37 & 1944,95 \\
Primorskiy Krai & Vladivostok & 1350,58 & 2310,81 \\
Republic of Sakha/Yakutiya & Yakutsk & 1407,25 & 2414,46 \\
Sakhalin Oblast & Yuzhno-Sakhalinsk & 1998,58 & 2284,5 \\
Khabarovsk Krai & Khabarovsk & 1608,58 & 2739,14 \\
\hline
\end{tabular}

Russian regions were also classified by their market potential (for retail sales) based on the data for 2005 and 2010 respectively.

For this purpose the market potential of Moscow and Moscow Oblast was taken as $100 \%$ since, according to our calculations, it is the maximum value. Relative values of the market potential of other regions were calculated as the ratio of the market potential of a region under consideration to the value of Moscow Oblast and Moscow's market potential. We introduced the following parameters of grouping regions based on their market potential value: $0-10 \%, 10-20 \%, 20-40 \%, 60-80 \%$ and $80-100 \%$.

The results are presented on the maps of Russia (Figures 1 \& 2).

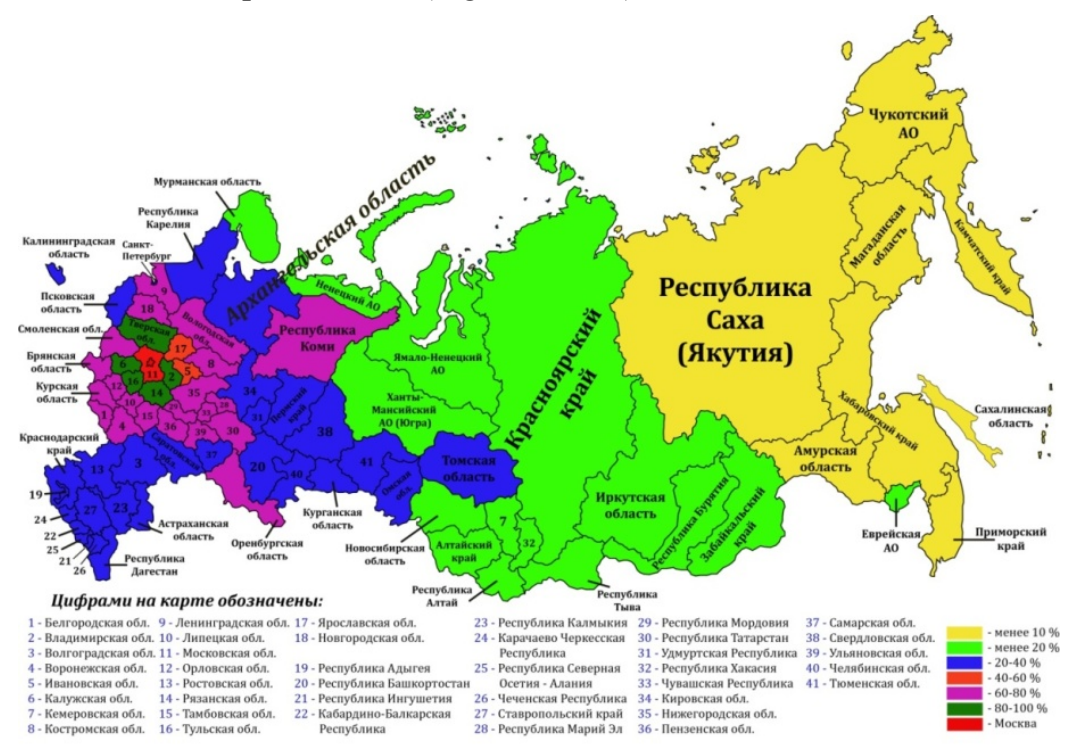

Figure 1. Market potential of Russian regions (retail markets), 2005

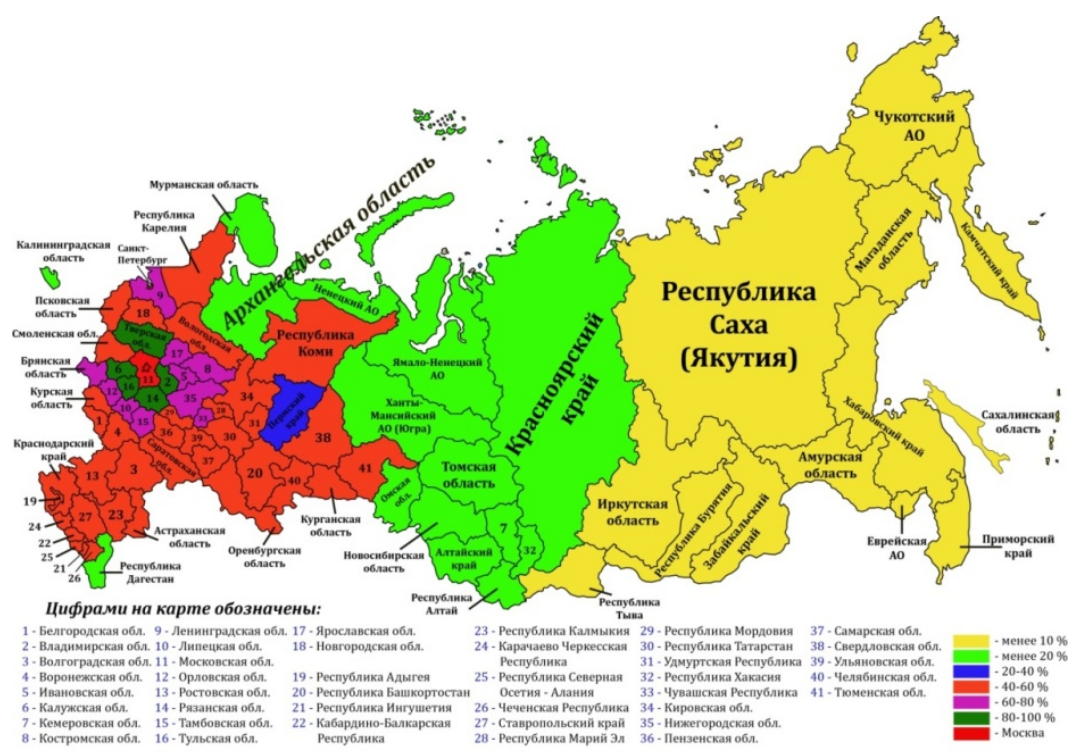

Figure 2. Market potential of Russian regions (retail markets), 2010 
The maps (Figures $1 \& 2$ ) show an inverse relationship between the market potential of Russia's regions and their proximity to the central region: the farther from Moscow a region is, the lower market potential it has. It proves our hypothesis of a high level of spatial differentiation of Russia's economic development. This puts bounds to comprehensive socio-economic development of the country.

Classification of Russian regions by their market potential resulted in 4 groups of regions (Tables $2 \& 3$ ).

Table 2. Classification of Russian regions by retail market potential, 2005

\begin{tabular}{|c|c|c|c|}
\hline $\begin{array}{c}\text { IV group } \\
0-20 \% \\
\end{array}$ & $\begin{array}{l}\text { III group } \\
20-60 \% \\
\end{array}$ & $\begin{array}{l}\text { II group } \\
60-80 \% \\
\end{array}$ & $\begin{array}{l}\text { I group } \\
80-100 \% \\
\end{array}$ \\
\hline Republic of Sakha (Yakutiya) & Arkhangelsk Oblast & Leningrad Oblast & $\begin{array}{c}\text { Moscow } \\
\text { Moscow } \\
\text { Oblast }\end{array}$ \\
\hline Nenets Autonomous Okrug & Ivanovo Oblast & & Tver Oblast \\
\hline $\begin{array}{l}\text { Chukchi Autonomous Okrug } \\
\text { Yamalo-Nenetskiy }\end{array}$ & Kaliningrad Oblast & Saint-Petersburg & $\begin{array}{l}\text { Vladimir } \\
\text { Oblast }\end{array}$ \\
\hline $\begin{array}{c}\text { Avtonomnyy Okrug } \\
\text { Magadan Oblast } \\
\text { Jewish Autonomous Oblast }\end{array}$ & Pskov Oblast & Novgorod Oblast & Kaluga Oblast \\
\hline $\begin{array}{c}\text { Kamchatka Krai } \\
\text { Trans-Baikal Krai }\end{array}$ & Republic of Karelia & Vologda Oblast & Tula Oblast \\
\hline $\begin{array}{c}\text { Khabarovsk Krai } \\
\text { Republic of Buryatiya }\end{array}$ & Kirov Oblast & Republic of Komi & $\begin{array}{l}\text { 7. Ryazan } \\
\text { Oblast }\end{array}$ \\
\hline $\begin{array}{l}\text { Sakhalin Oblast } \\
\text { Republic of Tyva }\end{array}$ & Republic of Udmurtiya & Smolensk Oblast & \\
\hline $\begin{array}{l}\text { Amur Oblast } \\
\text { Irkutsk Oblast }\end{array}$ & Perm Krai & Kostroma Oblast & \\
\hline $\begin{array}{l}\text { Primorskiy Krai } \\
\text { Krasnoyarsk Krai }\end{array}$ & Republic of Bashkortostan & $\begin{array}{l}\text { Nyzhniy Novgorod } \\
\text { Oblast }\end{array}$ & \\
\hline $\begin{array}{c}\text { Khanty-Mansi Autonomous } \\
\text { Okrug }\end{array}$ & Chelyabinsk Oblast & Respublika Mariy El & \\
\hline Novosibirsk Oblast & Sverdlov Oblast & Republic of Chuvashia & \\
\hline Altai Krai & Kurgan Oblast & Republic of Tatarstan & \\
\hline Republic of Altay & Tyumen Oblast & Orenburg Oblast & \\
\hline Republic of Khakasiya & Omsk Oblast & Ulyanovsk Oblast & \\
\hline Kemerovo Oblast & Tomsk Oblast & Respublika Mordoviya & \\
\hline \multirow[t]{15}{*}{ 23. Murmansk Oblast } & Samara Oblast & Penza Oblast & \\
\hline & Saratov Oblast & Tambov Oblast & \\
\hline & Volgograd Oblast & Lipetsk Oblast & \\
\hline & Rostov Oblast & Orel Oblast & \\
\hline & Republic of Kalmykia & Bryansk Oblast & \\
\hline & Astrakhan Oblast & Kursk Oblast & \\
\hline & Krasnodar Krai & Belgorod Oblast & \\
\hline & Stavropol Krai & 22. Voronezh Oblast & \\
\hline & Republic of Adygea & & \\
\hline & Karachay-Cherkess Republic & & \\
\hline & Kabardino-Balkaria & & \\
\hline & Republic of North Ossetia-Alania & & \\
\hline & Republic of Ingushetia & & \\
\hline & Chechen Republic & & \\
\hline & 31. Republic of Dagestan & & \\
\hline
\end{tabular}


Table 3. Classification of Russian regions by retail market potential, 2010

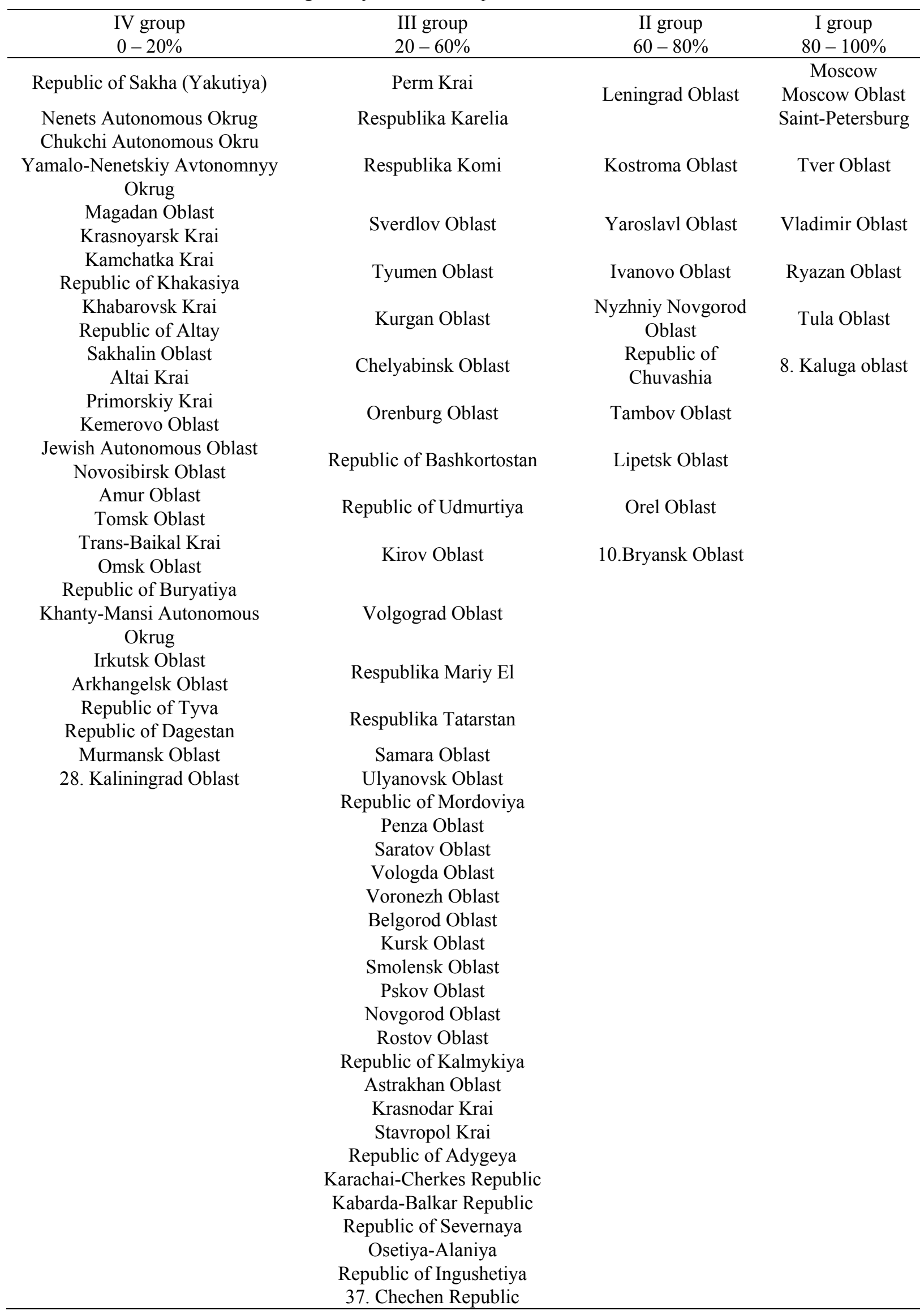


Tables 2 and 3 show that Russian regions are characterized by a significant spatial differentiation of the market potential: the maximum market potential concentrates in few regions, while the majority of the regions are characterized by a far less market potential. The $3^{\text {rd }}$ group of the regions (from 20 to $60 \%$ ) is the most numerous: it included 31 regions in 2005 and 37 in 2010. At the same time, the group with the maximum market potential (from 80 to $100 \%$ ) is the smallest in quantity: it included only 7 regions in 2005, and 8 regions in 2010 as Saint Petersburg moved from the $2^{\text {nd }}$ group to the leader group. The number of the regions in the $2^{\text {nd }}$ group (from 60 to $80 \%$ ) reduced from 22 in 2005 to 10 in 2010, as the rating positions of 11 regions became worse and they moved to the $3^{\text {rd }}$ and even $4^{\text {th }}$ groups. These results once again prove our hypothesis of a high and increasing level of spatial differentiation of Russia's economic development.

Based on the data of tables 2 and 3, we classified Russians regions by the dynamics of their market potential. We obtained three groups of regions: 1) regions with a stable market potential; 2) regions with an improved market potential; 3) regions with a decreased market potential. The results of the classification are presented in Table 4.

Table 4. Classification of Russian regions by retail market potential dynamics

\begin{tabular}{|c|c|c|}
\hline $\begin{array}{l}\text { Regions with a stable market } \\
\text { potential }\end{array}$ & $\begin{array}{c}\text { Regions with an improved market } \\
\text { potential }\end{array}$ & $\begin{array}{l}\text { Regions with an aggravated market } \\
\text { potential }\end{array}$ \\
\hline The Republic of Sakha (Yakutia) & Pskov Oblast & Jewish Autonomous Oblast \\
\hline Chukchi Autonomous Okrug & Kirov Oblast & Trans-Baikal Krai \\
\hline Magadan Oblast & Republic of Kareliya & Republic of Buryatiya \\
\hline Kamchatka Krai & Republic of Udmurtiya & Republic of Tuva \\
\hline Khabarovsk Krai & Republic of Bashkortostan & Irkutsk Oblast \\
\hline Sakhalin Oblast & Chelyabinsk Oblast & Arkhangelsk Oblast \\
\hline Amur Oblast & Sverdlov Oblast & Kaliningrad Oblast \\
\hline Primorsky Krai & Kurgan Oblast & Pskov Oblast \\
\hline Nenets Autonomous Okrug & Tyumen Oblast & Omsk Oblast \\
\hline $\begin{array}{c}\text { Yamalo-Nenets Autonomous } \\
\text { Okrug }\end{array}$ & Samara Oblast & Tomsk Oblast \\
\hline Krasnoyarsk Krai & Saratov Oblast & Republic of Dagestan \\
\hline $\begin{array}{l}\text { Khanty-Mansi Autonomous } \\
\text { Okrug }\end{array}$ & Volgograd Oblast & Novgorod Oblast \\
\hline Novosibirsk Oblast & Rostov Oblast & Vologda Oblast \\
\hline Altai Krai & Republic of Kalmykiya & Republic of Komi \\
\hline Republic of Altay & Astrakhan Oblast & Smolensk Oblast \\
\hline Republic of Khakasiya & Krasnodar Krai & Respublika Mariy El \\
\hline Kemerovo Oblast & Stavropol Krai & Respublika Tatarstan \\
\hline Murmansk Oblast & Republic of Adygeya & Orenburg Oblast \\
\hline Perm Krai & Karachai-Cherkes Republic & Ulyanovsk Oblast \\
\hline Leningrad Oblast & Kabarda-Balkar Republic & Republic of Mordoviya \\
\hline Kostroma Oblast & $\begin{array}{l}\text { Republic of Severnaya } \\
\text { Osetiya-Alaniya }\end{array}$ & Penza Oblast \\
\hline Nizhny Novgorod Oblast & Republic of Ingushetiya & Kursk Oblast \\
\hline Republic of Chuvashia & Chechen Republic & Belgorod Oblast \\
\hline Tambov Oblast & Ivanovo Oblast & 24.Voronezh Oblast \\
\hline Lipetsk Oblast & Yaroslavl Oblast & \\
\hline Orel Oblast & 26. Saint-Petersburg & \\
\hline \multicolumn{3}{|l|}{ Bryansk Oblast } \\
\hline \multicolumn{3}{|l|}{ Tver Oblast } \\
\hline \multicolumn{3}{|l|}{ Vladimir Oblast } \\
\hline \multicolumn{3}{|l|}{ Kaluga Oblast } \\
\hline \multicolumn{3}{|l|}{ Tula Oblast } \\
\hline 32.Ryazan Oblast & & \\
\hline
\end{tabular}

Table 4 shows change in the market potential of Russian regions over the indicated period of time: 24 regions are characterized by decrease in their market potential, 26 regions are marked by the market potential growth, and 
the market potential did not change in 32 regions. This says about slow positive dynamics of economic development in most regions of Russia.

\subsection{Casual Relationship between Factors of Business Location in Russian Regions}

Casual relationships between the selected factors of business location in Russian regions were established with the help of the correlation-regression analysis. The volume of fixed asset investment in a region was taken as an explained variable Y, characterizing business location in a region. Explaining variables include:

$\mathrm{X} 1$ - the retail market potential;

$\mathrm{X} 2$ - the number of economically active population in the regions;

$\mathrm{X} 3$ - the average nominal monthly wage in the regions.

The correlation-regression analysis was based on the data on Russian regions for 2005 and 2010 from the Central statistical database of the Federal State Statistics Service of the Russian Federation.

We created pairwise comparison matrices of correlation between the values of the selected factors in 2005 and 2010 (Tables 5, 6).

Table 5. Correlation pairwise comparison matrix (2005)

\begin{tabular}{ccccc}
\hline & $\mathrm{Y}$ & $\mathrm{X} 1$ & $\mathrm{X} 2$ & $\mathrm{X} 3$ \\
\hline $\mathrm{Y}$ & 1 & 0.2629 & 0.7601 & 0.5683 \\
$\mathrm{X} 1$ & 0.2629 & 1 & 0.4379 & -0.0844 \\
$\mathrm{X} 2$ & 0.7601 & 0.4379 & 1 & 0.1569 \\
$\mathrm{X} 3$ & 0.5683 & -0.0844 & 0.1569 & 1 \\
\hline
\end{tabular}

Table 6. Correlation pairwise comparison matrix (2010)

\begin{tabular}{ccccc}
\hline & $\mathrm{Y}$ & $\mathrm{X} 1$ & $\mathrm{X} 2$ & $\mathrm{X} 3$ \\
\hline $\mathrm{Y}$ & 1 & 0.2164 & 0.7209 & 0.5401 \\
$\mathrm{X} 1$ & 0.2164 & 1 & 0.4721 & -0.0296 \\
$\mathrm{X} 2$ & 0.7209 & 0.4721 & 1 & 0.2544 \\
$\mathrm{X} 3$ & 0.5401 & -0.0296 & 0.2544 & 1 \\
\hline
\end{tabular}

These correlation matrices show that factors X2 and X3 are significant both in 2005 and 2010, which means a strong linear relationship between the volume of fixed asset investment, the number of economically active population and the average nominal monthly wage. At the same time factor X1 turned out to be insignificant meaning the absence of correlation between the volume of fixed asset investment and the region's market potential. As correlation between the factors is not very high, the problem of multicollinearity should not arise.

The multiple regression equation in a linear form is written as:

1) based on data for 2005 :

$$
Y=-80823.36+0.0049 * X 1+59.439 * X 2+9.351 * X 3
$$

General characteristics of the obtained model:

\begin{tabular}{cc}
\hline Regression statistics & \\
\hline Multiple R & 0.8857 \\
R-squared & 0.7845 \\
Normalized R-squared & 0.7760 \\
Standard error & 35588.14 \\
Observation & 80 \\
\hline
\end{tabular}

Variance analysis

\begin{tabular}{cccccc}
\hline & $d f$ & $S S$ & $M S$ & $F$ & Significance $F$ \\
\hline Regression & 3 & $3.505 \mathrm{E}+11$ & $1.17 \mathrm{E}+11$ & 92.2455 & $2.91 \mathrm{E}-25$ \\
Excess & 76 & $9.626 \mathrm{E}+10$ & $1.27 \mathrm{E}+09$ & & \\
Total & 79 & $4.467 \mathrm{E}+11$ & & & \\
\hline
\end{tabular}




\begin{tabular}{ccccc}
\hline & Coefficients & Standard error & t-statistics & $P$-Value \\
\hline Y-intersection & -80823.36 & 10354.61 & -7.806 & $2.59 \mathrm{E}-11$ \\
Variable X1 & 0.0049 & 0.403 & 0.012 & 0.990 \\
Variable X2 & 59.439 & 5.244 & 11.334 & $5.32 \mathrm{E}-18$ \\
Variable X3 & 9.351 & 1.111 & 8.414 & $1.77 \mathrm{E}-12$ \\
\hline
\end{tabular}

The obtained model is characterized by a rather high value of determination coefficient $\left(R^{2}=0.7845\right)$, which means that the model is reliable enough. The model is also significant, since F-statistic has a large value. However, according to t-test results, factor $\mathrm{X} 1$ is not significant (P-value is close to 1).

Figure 3 shows a graph of the explained value (the volume of fixed asset investment) and values obtained from the model.

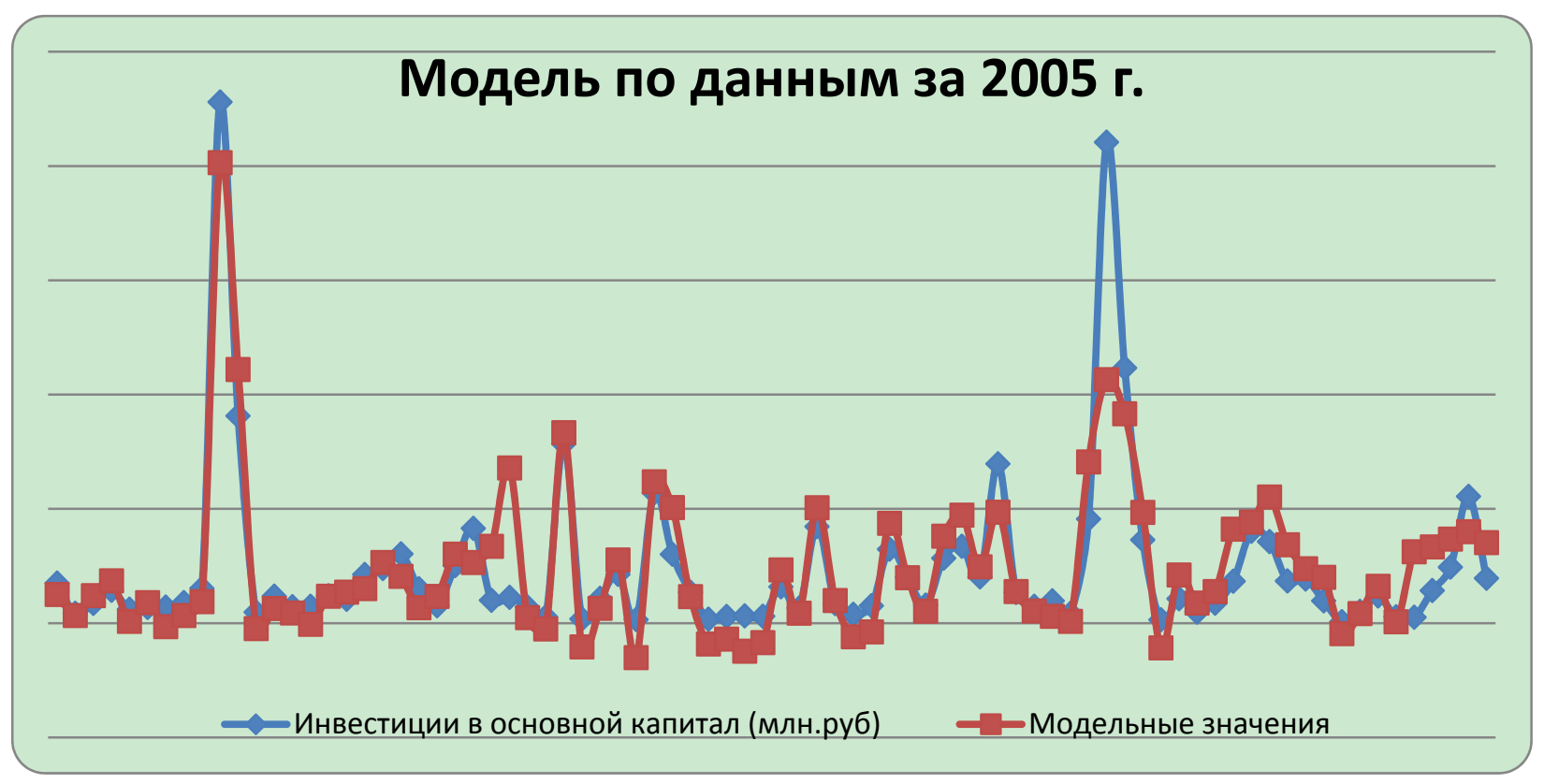

Figure 3. A model of fixed asset investment based on data for 2005

2) Based on data for 2010 :

$$
Y=-136312.96-0.898 * X 1+123.83 * X 2+8.355 * X 3
$$

General characteristics of the obtained model:

\begin{tabular}{cc}
\hline \multicolumn{1}{c}{ Regression statistics } \\
\hline Multiple R \\
R-squared & 0.8135 \\
Normalized R-squared & 0.6617 \\
Standard error & 0.6484 \\
Observation & 99340.48 \\
\hline
\end{tabular}

Variance analysis

\begin{tabular}{cccccc}
\hline & $d f$ & $S S$ & $M S$ & $F$ & Significance $F$ \\
\hline Regression & 3 & $1.467 \mathrm{E}+12$ & $4.89 \mathrm{E}+11$ & 49.5523 & $7.46 \mathrm{E}-18$ \\
Excess & 76 & $7.5 \mathrm{E}+11$ & $9.87 \mathrm{E}+09$ & & \\
Total & 79 & $2.217 \mathrm{E}+12$ & & & \\
\hline
\end{tabular}




\begin{tabular}{ccccc}
\hline & Coefficients & Standard error & t-statistics & $P$-Value \\
\hline Y-intersection & -136312.96 & 32320.6 & -4.218 & $6.75 \mathrm{E}-05$ \\
Variable X1 & -0.898 & 0.779 & -1.154 & 0.252 \\
Variable X2 & 123.83 & 14.699 & 8.424 & $1.69 \mathrm{E}-12$ \\
VariableX3 & 8.355 & 1.595 & 5.240 & $1.39 \mathrm{E}-06$ \\
\hline
\end{tabular}

As compared to the model obtained for 2005 , the model for 2010 has smaller values of $R^{2}$ and $F$-statistics, but it is well significant. Similar to the model obtained for 2005, the model for 2010 has significant factors X2 and X3 and insignificant factor X1. Nevertheless, P-value of factor X1 is much less in the second model than in the first one.

Figure 4 shows a graph of the fixed asset investment and model values for 2010.

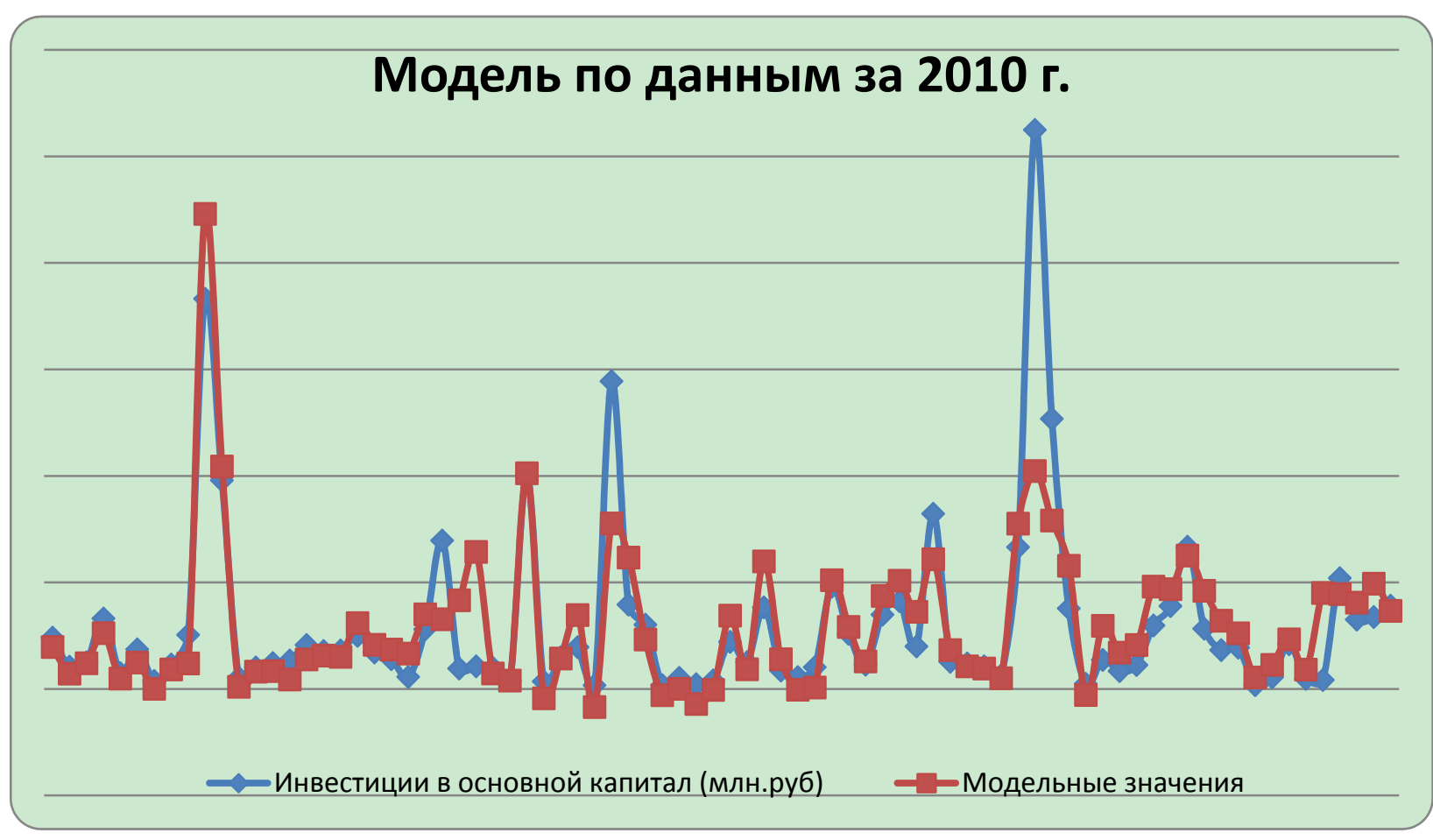

Figure 4. A model of fixed asset investment based on data for 2010

So, correlation-regression analysis showed that our hypothesis that business location in Russian regions is determined by such factors as the market potential, the number of economically active population and the average nominal monthly wage is partially true. According to the obtained results, there is a strong linear relationship between the volume of fixed asset investment and such factors as the number of economically active population and the average nominal monthly wage while the amount of fixed asset investment does not correlate with the retail market potential.

\subsection{Classification of the Regions}

Russian regions were clustered on the basis of 5 variables: aggregates and the main useful function $F$. The latter allows a clear and simple interpretation of calculation results.

Using the initial values of parameters, we rated each region of the Russian Federation based on the selected indicators by means of the Kohonen layer and self-organizing net. Further we summed up rating positions of every region and grouped the regions.

The calculation results for the selected variables in Russian regions for 2005 and 2010 are given in Tables 7 and 8 , where column $A$ is the classification of regions by their retail market potential, $B$ is the classification of regions with the help of the Kohonen layer, column $C$ is the classification of regions by means of the 
self-organizing net, $x_{1}$ is the classification by fixed capital investment, $x_{2}$ is the classification by economically active population, $x_{3}$ is the classification by the average monthly nominal wage, and column $D$ is the total rating of a region.

Table 7. Ratings of Russian regions, 2005

\begin{tabular}{|c|c|c|c|c|c|c|c|c|}
\hline \multirow{2}{*}{ Subject of the Federation } & \multirow{2}{*}{$\mathbf{A}$} & \multicolumn{3}{|c|}{ B } & \multicolumn{3}{|c|}{$\mathbf{C}$} & \multirow{2}{*}{$\begin{array}{c}\text { Total places } \\
\text { D } \\
\end{array}$} \\
\hline & & $\mathbf{x 1}$ & $\mathbf{x 2}$ & $\mathbf{X 3}$ & $\mathbf{x 1}$ & $\mathbf{x 2}$ & $\mathbf{x} 3$ & \\
\hline 1 & 4 & 5 & 6 & 7 & 8 & 9 & 10 & 11 \\
\hline Belgorod Oblast & 2 & 1 & 1 & 3 & 1 & 1 & 3 & 14 \\
\hline Bryansk Oblast & 2 & 1 & 1 & 2 & 1 & 1 & 2 & 12 \\
\hline Vladimir Oblast & 3 & 1 & 1 & 2 & 1 & 1 & 2 & 15 \\
\hline Voronezh Oblast & 2 & 1 & 2 & 2 & 1 & 2 & 2 & 14 \\
\hline Ivanovo Oblast & 3 & 1 & 1 & 2 & 1 & 1 & 2 & 14 \\
\hline Kaluga Oblast & 3 & 1 & 1 & 3 & 1 & 1 & 3 & 17 \\
\hline Kostroma Oblast & 2 & 1 & 1 & 2 & 1 & 1 & 2 & 13 \\
\hline Kursk Oblast & 2 & 1 & 1 & 2 & 1 & 1 & 2 & 12 \\
\hline Lipetsk Oblast & 2 & 1 & 2 & 3 & 1 & 1 & 3 & 15 \\
\hline Moscow & 4 & 4 & 4 & 4 & 4 & 4 & 4 & 32 \\
\hline Moscow Oblast & 4 & 3 & 3 & 4 & 2 & 3 & 4 & 27 \\
\hline Orel Oblast & 2 & 1 & 1 & 2 & 1 & 1 & 3 & 14 \\
\hline Ryazan Oblast & 3 & 1 & 1 & 2 & 1 & 1 & 2 & 15 \\
\hline Smolensk Oblast & 2 & 1 & 1 & 3 & 1 & 1 & 3 & 14 \\
\hline Tambov Oblast & 2 & 1 & 2 & 2 & 1 & 1 & 2 & 13 \\
\hline Tver Oblast & 3 & 1 & 1 & 3 & 1 & 1 & 3 & 17 \\
\hline Tula Oblast & 3 & 1 & 1 & 3 & 1 & 1 & 3 & 17 \\
\hline Yaroslavl Oblast & 3 & 1 & 1 & 3 & 1 & 1 & 3 & 16 \\
\hline Arkhangelsk Oblast & 1 & 1 & 1 & 4 & 1 & 1 & 4 & 14 \\
\hline Vologda Oblast & 2 & 1 & 2 & 1 & 1 & 2 & 2 & 13 \\
\hline Kaliningrad Oblast & 1 & 1 & 1 & 3 & 1 & 1 & 3 & 12 \\
\hline Republic of Kareliya & 1 & 1 & 2 & 3 & 1 & 1 & 3 & 13 \\
\hline Komi Republic & 2 & 1 & 2 & 4 & 1 & 1 & 4 & 16 \\
\hline Leningrad Oblast & 2 & 1 & 2 & 3 & 1 & 1 & 3 & 15 \\
\hline Murmansk Oblast & 1 & 1 & 1 & 4 & 1 & 1 & 3 & 13 \\
\hline Nenets Autonomous Okrug & 1 & 1 & 1 & 4 & 1 & 1 & 4 & 14 \\
\hline Novgorod Oblast & 2 & 1 & 1 & 3 & 1 & 1 & 3 & 14 \\
\hline Pskov Oblast & 2 & 1 & 1 & 2 & 1 & 1 & 2 & 12 \\
\hline Saint-Petersburg & 2 & 2 & 3 & 4 & 2 & 3 & 4 & 22 \\
\hline Republic of Adygeya & 2 & 1 & 1 & 2 & 1 & 1 & 2 & 11 \\
\hline Astrakhan Oblast & 1 & 1 & 2 & 3 & 1 & 1 & 3 & 13 \\
\hline Volgograd Oblast & 2 & 1 & 2 & 3 & 1 & 2 & 3 & 16 \\
\hline Kalmykia & 2 & 1 & 1 & 2 & 1 & 1 & 1 & 11 \\
\hline Krasnodar Krai & 2 & 2 & 3 & 3 & 2 & 3 & 3 & 19 \\
\hline Rostov Oblast & 2 & 1 & 3 & 2 & 1 & 3 & 2 & 16 \\
\hline
\end{tabular}




\begin{tabular}{|c|c|c|c|c|c|c|c|c|}
\hline Republic of Daghestan & 1 & 1 & 1 & 2 & 1 & 2 & 2 & 11 \\
\hline Ingush Republic & 1 & 1 & 1 & 2 & 1 & 1 & 2 & 10 \\
\hline Kabarda-Balkar Republic & 1 & 1 & 1 & 2 & 1 & 1 & 2 & 10 \\
\hline Karachai-Cherkes Republic & 1 & 1 & 1 & 2 & 1 & 1 & 2 & 10 \\
\hline Republic of North Ossetia - Alania & 1 & 1 & 1 & 2 & 1 & 1 & 2 & 10 \\
\hline Stavropol Krai & 1 & 1 & 2 & 1 & 1 & 2 & 2 & 11 \\
\hline Republic of Bashkortostan & 2 & 1 & 2 & 3 & 1 & 2 & 3 & 16 \\
\hline Kirov Oblast & 2 & 1 & 1 & 2 & 1 & 1 & 2 & 12 \\
\hline Republic of Mari El & 2 & 1 & 1 & 2 & 1 & 1 & 2 & 12 \\
\hline Republic of Mordovia & 2 & 1 & 1 & 2 & 1 & 1 & 2 & 12 \\
\hline Nyzhniy Novgorod Oblast & 2 & 1 & 2 & 3 & 1 & 2 & 3 & 16 \\
\hline Orenburg Oblast & 2 & 1 & 2 & 3 & 1 & 2 & 3 & 15 \\
\hline Penza Oblast & 2 & 1 & 1 & 2 & 1 & 1 & 1 & 11 \\
\hline Perm Krai & 2 & 1 & 2 & 3 & 1 & 2 & 2 & 15 \\
\hline Samara Oblast & 2 & 1 & 2 & 3 & 1 & 2 & 2 & 15 \\
\hline Saratov Oblast & 2 & 1 & 2 & 2 & 1 & 2 & 3 & 15 \\
\hline Republic of Tatarstan & 2 & 2 & 2 & 3 & 2 & 2 & 3 & 18 \\
\hline Republic of Udmurtiya & 2 & 1 & 1 & 3 & 1 & 1 & 3 & 14 \\
\hline Ulyanovsk Oblast & 2 & 1 & 1 & 2 & 1 & 1 & 2 & 12 \\
\hline Republic of Chuvashia & 2 & 1 & 1 & 2 & 1 & 1 & 3 & 13 \\
\hline Kurgan Oblast & 2 & 1 & 1 & 2 & 1 & 1 & 2 & 12 \\
\hline Sverdlov Oblast & 2 & 1 & 3 & 3 & 1 & 3 & 3 & 18 \\
\hline Tyumen Oblast & 1 & 4 & 2 & 4 & 4 & 2 & 4 & 22 \\
\hline Chelyabinsk Oblast & 2 & 1 & 2 & 3 & 1 & 2 & 3 & 16 \\
\hline Altai Republic & 1 & 1 & 1 & 2 & 1 & 1 & 2 & 10 \\
\hline Altai Krai & 1 & 1 & 1 & 2 & 1 & 2 & 3 & 12 \\
\hline Republic of Buryatia & 1 & 1 & 1 & 3 & 1 & 1 & 3 & 12 \\
\hline Trans-Baikal Krai & 1 & 1 & 1 & 1 & 1 & 1 & 2 & 9 \\
\hline Irkutsk Oblast & 1 & 1 & 2 & 4 & 1 & 2 & 4 & 16 \\
\hline Kemerovo Oblast & 1 & 1 & 1 & 3 & 1 & 1 & 3 & 12 \\
\hline Krasnoyarsk Krai & 1 & 4 & 2 & 4 & 4 & 2 & 4 & 22 \\
\hline Novosibirsk Oblast & 1 & 1 & 2 & 3 & 1 & 2 & 3 & 14 \\
\hline Omsk Oblast & 1 & 1 & 2 & 3 & 1 & 2 & 3 & 14 \\
\hline Tomsk Oblast & 1 & 1 & 2 & 4 & 1 & 1 & 4 & 15 \\
\hline Republic of Tyva & 1 & 1 & 1 & 3 & 1 & 1 & 3 & 12 \\
\hline Republic of Khakassia & 1 & 1 & 1 & 3 & 1 & 1 & 3 & 12 \\
\hline Amur Oblast & 1 & 1 & 1 & 3 & 1 & 1 & 2 & 11 \\
\hline Jewish Autonomous Region & 1 & 1 & 1 & 1 & 1 & 1 & 2 & 9 \\
\hline Magadan Oblast & 1 & 1 & 1 & 4 & 1 & 1 & 4 & 14 \\
\hline Primorskiy Krai & 1 & 1 & 1 & 3 & 1 & 2 & 3 & 13 \\
\hline Republic of Sakha/Yakutiya & 1 & 1 & 2 & 1 & 1 & 1 & 2 & 10 \\
\hline Sakhalin Oblast & 1 & 1 & 1 & 4 & 1 & 1 & 4 & 14 \\
\hline Khabarovsk Krai & 1 & 1 & 1 & 4 & 1 & 1 & 4 & 14 \\
\hline
\end{tabular}


Table 8. Ratings of Russian regions, 2010

\begin{tabular}{|c|c|c|c|c|c|c|c|c|}
\hline \multirow{2}{*}{ Subject of the Federation } & \multirow{2}{*}{$\mathbf{A}$} & \multicolumn{3}{|c|}{ B } & \multicolumn{3}{|c|}{$\mathbf{C}$} & \multirow{2}{*}{$\begin{array}{c}\text { Total places } \\
\text { D }\end{array}$} \\
\hline & & $\mathbf{x 1}$ & $\mathbf{x 2}$ & $\mathbf{x} 3$ & $\mathbf{x 1}$ & $\mathbf{x 2}$ & $\mathbf{x} 3$ & \\
\hline 1 & 4 & 5 & 6 & 7 & 8 & 9 & 10 & 11 \\
\hline Belgorod Oblast & 2 & 1 & 1 & 2 & 1 & 1 & 2 & 12 \\
\hline Bryansk Oblast & 2 & 1 & 1 & 2 & 1 & 1 & 2 & 13 \\
\hline Vladimir Oblast & 4 & 1 & 2 & 2 & 1 & 2 & 2 & 18 \\
\hline Voronezh Oblast & 2 & 2 & 2 & 2 & 3 & 2 & 2 & 18 \\
\hline Ivanovo Oblast & 3 & 1 & 1 & 2 & 1 & 1 & 2 & 15 \\
\hline Kaluga Oblast & 4 & 1 & 1 & 3 & 1 & 1 & 2 & 17 \\
\hline Kostroma Oblast & 3 & 1 & 1 & 2 & 1 & 1 & 2 & 15 \\
\hline Kursk Oblast & 2 & 1 & 1 & 2 & 1 & 1 & 2 & 13 \\
\hline Lipetsk Oblast & 3 & 2 & 1 & 2 & 2 & 1 & 3 & 17 \\
\hline Moscow & 4 & 4 & 4 & 4 & 4 & 4 & 4 & 32 \\
\hline Moscow Oblast & 4 & 3 & 3 & 3 & 4 & 3 & 3 & 27 \\
\hline Orel Oblast & 3 & 1 & 1 & 2 & 1 & 1 & 2 & 14 \\
\hline Ryazan Oblast & 4 & 1 & 1 & 2 & 1 & 1 & 2 & 13 \\
\hline Smolensk Oblast & 2 & 1 & 1 & 2 & 1 & 1 & 2 & 13 \\
\hline Tambov Oblast & 3 & 1 & 1 & 2 & 1 & 1 & 2 & 14 \\
\hline Tver Oblast & 4 & 1 & 1 & 2 & 1 & 1 & 2 & 16 \\
\hline Tula Oblast & 4 & 1 & 1 & 2 & 1 & 1 & 2 & 16 \\
\hline Yaroslavl Oblast & 3 & 1 & 1 & 2 & 1 & 2 & 2 & 16 \\
\hline Arkhangelsk Oblast & 1 & 1 & 1 & 3 & 1 & 2 & 3 & 14 \\
\hline Vologda Oblast & 2 & 1 & 2 & 2 & 1 & 2 & 3 & 15 \\
\hline Kaliningrad Oblast & 1 & 1 & 1 & 3 & 1 & 1 & 3 & 13 \\
\hline Republic of Kareliya & 2 & 1 & 1 & 3 & 1 & 1 & 3 & 14 \\
\hline Komi Republic & 1 & 2 & 1 & 4 & 1 & 1 & 4 & 16 \\
\hline Leningrad Oblast & 3 & 3 & 1 & 3 & 3 & 1 & 3 & 20 \\
\hline Murmansk Oblast & 1 & 1 & 1 & 4 & 1 & 1 & 4 & 14 \\
\hline Nenets Autonomous Okrug & 1 & 1 & 1 & 4 & 1 & 1 & 4 & 14 \\
\hline Novgorod Oblast & 2 & 1 & 1 & 3 & 1 & 1 & 3 & 15 \\
\hline Pskov Oblast & 2 & 1 & 1 & 2 & 1 & 1 & 2 & 12 \\
\hline Saint-Petersburg & 2 & 4 & 3 & 4 & 4 & 3 & 4 & 26 \\
\hline Republic of Adygeya & 2 & 1 & 1 & 2 & 1 & 1 & 2 & 12 \\
\hline Astrakhan Oblast & 2 & 1 & 1 & 3 & 1 & 1 & 2 & 13 \\
\hline Volgograd Oblast & 2 & 1 & 1 & 3 & 1 & 1 & 3 & 15 \\
\hline Kalmykia & 2 & 1 & 1 & 2 & 1 & 1 & 1 & 11 \\
\hline Krasnodar Krai & 2 & 4 & 3 & 2 & 4 & 2 & 3 & 22 \\
\hline Rostov Oblast & 2 & 2 & 2 & 2 & 2 & 1 & 2 & 15 \\
\hline Republic of Daghestan & 1 & 2 & 2 & 2 & 2 & 2 & 2 & 14 \\
\hline Ingush Republic & 2 & 1 & 1 & 2 & 1 & 1 & 2 & 12 \\
\hline Kabarda-Balkar Republic & 2 & 1 & 1 & 2 & 1 & 1 & 2 & 12 \\
\hline Karachai-Cherkes Republic & 2 & 1 & 1 & 2 & 1 & 1 & 2 & 12 \\
\hline
\end{tabular}


Republic of North Ossetia Alania

Stavropol Krai

Republic of Bashkortostan

Kirov Oblast

Republic of Mari El

Republic of Mordovia

Nyzhniy Novgorod Oblast

Orenburg Oblast

Penza Oblast

Perm Krai

Samara Oblast

Saratov Oblast

Republic of Tatarstan

Republic of Udmurtiya

Ulyanovsk Oblast

Republic of Chuvashia

Kurgan Oblast

Sverdlov Oblast

Tyumen Oblast

Chelyabinsk Oblast

Altai Republic

Altai Krai

Republic of Buryatia

Trans-Baikal Krai

Irkutsk Oblast

Kemerovo Oblast

Krasnoyarsk Krai

Novosibirsk Oblast

Omsk Oblast

Tomsk Oblast

Republic of Tyva

Republic of Khakassia

Amur Oblast

Jewish Autonomous Region

Magadan Oblast

Primorskiy Krai

Republic of Sakha/Yakutiya

Sakhalin Oblast

Khabarovsk Krai

$\begin{array}{llll}2 & 1 & 1 & 2\end{array}$

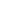

$\begin{array}{llllllll}2 & 1 & 2 & 2 & 1 & 2 & 2 & 14\end{array}$

$\begin{array}{llllllll}2 & 2 & 2 & 3 & 2 & 2 & 3 & 18\end{array}$

$\begin{array}{llllllll}2 & 1 & 1 & 2 & 1 & 1 & 2 & 12\end{array}$

$\begin{array}{llllllll}2 & 1 & 1 & 2 & 1 & 1 & 2 & 13\end{array}$

$\begin{array}{llllllll}2 & 1 & 1 & 2 & 1 & 2 & 2 & 14\end{array}$

$\begin{array}{llllllll}2 & 2 & 2 & 3 & 2 & 2 & 3 & 14\end{array}$

$\begin{array}{llllllll}2 & 2 & 2 & 2 & 1 & 2 & 3 & 16\end{array}$

$\begin{array}{llllllll}2 & 1 & 1 & 2 & 1 & 1 & 1 & 16 \\ 2 & 2 & 2 & 3 & 3 & 2 & 3 & 18\end{array}$

$\begin{array}{rrrrrrrr}2 & 2 & 2 & 3 & 3 & 2 & 3 & 18 \\ 2 & 2 & 2 & 3 & 2 & 2 & 3 & 17\end{array}$

$\begin{array}{llllllll}2 & 2 & 2 & 3 & 2 & 2 & 3 & 17 \\ 2 & 1 & 2 & 2 & 1 & 2 & 3 & 14 \\ 2 & 3 & 2 & 3 & 3 & 2 & 3 & 19\end{array}$

$\begin{array}{llllllll}2 & 3 & 2 & 3 & 3 & 2 & 3 & 19 \\ 2 & 1 & 1 & 2 & 1 & 1 & 2 & 11\end{array}$

$\begin{array}{llllllll}2 & 1 & 1 & 2 & 1 & 1 & 1 & 10 \\ 2 & 1 & 1 & 2 & 1 & 1 & 2 & 13\end{array}$

$\begin{array}{llllllll}2 & 1 & 1 & 2 & 1 & 1 & 2 & 13 \\ 2 & 3 & 3 & 3 & 2 & 2 & 3 & 12 \\ 2 & 4 & 2 & 4 & 4 & 2 & 4 & 24\end{array}$

$\begin{array}{llllllll}2 & 4 & 2 & 4 & 4 & 2 & 4 & 24\end{array}$

$\begin{array}{llllllll}2 & 2 & 2 & 3 & 2 & 2 & 3 & 18\end{array}$

$\begin{array}{llllllll}2 & 2 & 2 & 3 & 2 & 2 & 3 & 18 \\ 1 & 1 & 1 & 2 & 1 & 1 & 2 & 10 \\ 1 & 1 & 2 & 2 & 1 & 2 & 2 & 12\end{array}$

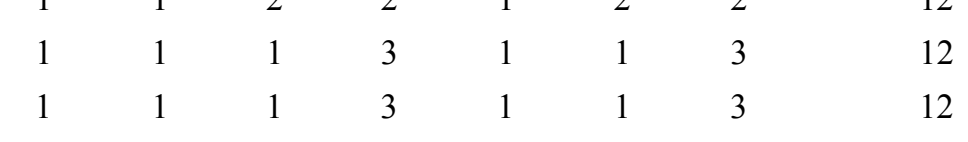

$\begin{array}{llllllll}1 & 1 & 1 & 3 & 1 & 1 & 3 & 12 \\ 1 & 2 & 1 & 3 & 2 & 1 & 2 & 13 \\ 1 & 2 & 2 & 3 & 2 & 2 & 3 & 16\end{array}$

$\begin{array}{llllllll}1 & 4 & 2 & 4 & 4 & 2 & 3 & 16\end{array}$

$\begin{array}{llllllll}1 & 4 & 2 & 4 & 4 & 2 & 3 & 21 \\ 1 & 2 & 2 & 3 & 2 & 2 & 3 & 16 \\ 1 & 1 & 2 & 3 & 1 & 2 & 3 & 14\end{array}$

$\begin{array}{llllllll}1 & 1 & 1 & 3 & 1 & 1 & 3 & 12 \\ 1 & 1 & 1 & 3 & 1 & 1 & 3 & 12\end{array}$

$\begin{array}{llllllll}1 & 1 & 1 & 3 & 1 & 1 & 3 & 12 \\ 1 & 1 & 1 & 3 & 1 & 1 & 3 & 12\end{array}$

$\begin{array}{llllllll}1 & 1 & 1 & 3 & 1 & 1 & 3 & 12 \\ 1 & 1 & 1 & 3 & 1 & 1 & 3 & 12\end{array}$

$\begin{array}{cccccccc}1 & 1 & 1 & 3 & 1 & 1 & 3 & 12 \\ 1 & 1 & 2 & 1 & 1 & 1 & 1 & 9\end{array}$

$\begin{array}{cccccccc}1 & 1 & 2 & 1 & 1 & 1 & 1 & 9 \\ 1 & 1 & 1 & 4 & 1 & 1 & 4 & 14\end{array}$

$\begin{array}{llllllll}1 & 1 & 1 & 4 & 1 & 1 & 4 & 14 \\ 1 & 2 & 2 & 3 & 2 & 2 & 3 & 16 \\ 1 & 2 & 1 & 4 & 2 & 1 & 4 & 16\end{array}$

$\begin{array}{llllllll}1 & 2 & 1 & 4 & 2 & 1 & 3 & 16 \\ 1 & 2 & 1 & 3 & 2 & 2 & 3\end{array}$

$\begin{array}{lllllll}1 & 2 & 1 & 3 & 2 & 2 & 3\end{array}$

11

4

(3)

3

4

9

6

8

7

4

9

1

0

3

2

0

4

8

(1)

2

2

2

3

1

6

4

2

2

2

2

14
6
6
5
15

The comparative analysis of the calculation results using the Kohonen layer and self-organizing net (Tables 7, 8 , Columns A and B) reveals that the work of the Kohonen layer slightly differs from the work of the self-organizing network. In some cases the self-organizing network omitted one group while classifying the 
regions. That is why it is useful to apply both the Kohonen layer and the self-organizing network in order to improve accuracy of the calculation.

The calculation results in tables 7 and 8 allow to segment the regions. In our research we identified 4 groups of regions from the most attractive to the least attractive for investors to locate a business in accordance with the criterion in column D: the first group includes the most attractive regions and the forth one - the least attractive (Tables 9, 10).

Table 9. Classification of Russian regions by attractiveness for investors to locate a business, 2005

\begin{tabular}{|c|c|c|c|}
\hline $\begin{array}{l}\text { I group } \\
(28-23)\end{array}$ & $\begin{array}{l}\text { II group } \\
(22-18)\end{array}$ & $\begin{array}{c}\text { III group } \\
(17-13)\end{array}$ & $\begin{array}{l}\text { IV group } \\
(12-8)\end{array}$ \\
\hline $\begin{array}{c}\text { Moscow } \\
\text { Moscow Oblast }\end{array}$ & $\begin{array}{c}\text { Saint-Petersburg } \\
\text { Krasnodar Krai } \\
\text { Tyumen Oblast } \\
\text { Krasnoyarsk Krai }\end{array}$ & $\begin{array}{c}\text { Kaluga Oblast } \\
\text { Lipetsk Oblast } \\
\text { Tver Oblast } \\
\text { Tula Oblast } \\
\text { Yaroslavl Oblast } \\
\text { Arkhangelsk Oblast } \\
\text { Republic of Komi } \\
\text { Leningrad Oblast } \\
\text { Nenets Autonomous Okrug } \\
\text { Volgograd Oblast } \\
\text { Rostov Oblast } \\
\text { Republic of Bashkortostan } \\
\text { Nyzhniy Novgorod Oblast } \\
\text { Orenburg Oblast } \\
\text { Perm Krai } \\
\text { Samara Oblast } \\
\text { Saratov Oblast } \\
\text { Republic of Tatarstan } \\
\text { Sverdlov Oblast } \\
\text { Chelyabinsk Oblast } \\
\text { Irkutsk Oblast } \\
\text { Novosibirsk Oblast } \\
\text { Omsk Oblast } \\
\text { Tomsk Oblast } \\
\text { Magadan Oblast } \\
\text { Sakhalin Oblast } \\
\text { Khabarovsk Krai }\end{array}$ & $\begin{array}{c}\text { Belgorod Oblast } \\
\text { Bryansk Oblast } \\
\text { Tver Oblast } \\
\text { Tula Oblast } \\
\text { Yaroslavl Oblast } \\
\text { Arkhangelsk Oblast } \\
\text { Kursk Oblast } \\
\text { Orel Oblast } \\
\text { Ryazan Oblast } \\
\text { Smolensk Oblast } \\
\text { Tambov Oblast } \\
\text { Vologda Oblast } \\
\text { Kaliningrad Oblast } \\
\text { Respublika Kareliya } \\
\text { Murmansk Oblast } \\
\text { Novgorod Oblast } \\
\text { Pskov Oblast } \\
\text { Respublika Adygeya } \\
\text { Astrakhan Oblast } \\
\text { Respublika Kalmykiya } \\
\text { Respublika Dagestan } \\
\text { Respublika Ingushetiya } \\
\text { Kabarda-Balkar Republic } \\
\text { Karachai-Cherkes Republic } \\
\text { Republic of North Ossetia - Alania } \\
\text { Stavropol Krai } \\
\text { Kirov Oblast } \\
\text { Republic of Mariy El } \\
\text { Republic of Mordoviya } \\
\text { Penza Oblast } \\
\text { Republic of Udmurtiya } \\
\text { Ulyanovsk Oblast } \\
\text { Republic of Chuvashia } \\
\text { Kurgan Oblast } \\
\text { Republic of Altay } \\
\text { Altai Krai } \\
\text { Republic of Buryatiya } \\
\text { Trans-Baikal Krai } \\
\text { Kemerovo Oblast } \\
\text { Republic of Tyva } \\
\text { Republic of Khakasiya } \\
\text { Amur Oblast } \\
\text { Jewish Autonomous Oblast } \\
\text { Primorskiy Krai } \\
\text { Republic of Sakha (Yakutiva) }\end{array}$ \\
\hline
\end{tabular}


Table 10. Classification of Russian regions by attractiveness for investors to locate a business, 2010

\begin{tabular}{|c|c|c|c|}
\hline $\begin{array}{l}\text { I group } \\
(28-23)\end{array}$ & $\begin{array}{r}\text { II group } \\
(22-18) \\
\end{array}$ & $\begin{array}{c}\text { III group } \\
(17-13)\end{array}$ & $\begin{array}{c}\text { IV group } \\
(12-8)\end{array}$ \\
\hline $\begin{array}{c}\text { Moscow } \\
\text { Moscow Oblast } \\
\text { Saint-Petersburg }\end{array}$ & $\begin{array}{c}\text { Krasnodar Krai } \\
\text { Republic of Tatarstan } \\
\text { Sverdlov Oblast } \\
\text { Krasnoyarsk Krai } \\
\text { Tyumen Oblast }\end{array}$ & $\begin{array}{c}\text { Vladimir Oblast } \\
\text { Voronezh Oblast } \\
\text { Kaluga Oblast } \\
\text { Lipetsk Oblast } \\
\text { Vologda Oblast } \\
\text { Republic of Komi } \\
\text { Leningrad Oblast } \\
\text { Murmansk Oblast } \\
\text { Nenets Autonomous Okrug } \\
\text { Rostov Oblast } \\
\text { Republic of Dagestan } \\
\text { Republic of Bashkortostan } \\
\text { Nyzhniy Novgorod Oblast } \\
\text { Orenburg Oblast } \\
\text { Perm Krai } \\
\text { Samara Oblast } \\
\text { Saratov Oblast } \\
\text { Chelyabinsk Oblast } \\
\text { Kemerovo Oblast } \\
\text { Novosibirsk Oblast } \\
\text { Omsk Oblast } \\
\text { Magadan Oblast } \\
\text { Primorskiy Krai } \\
\text { Republic of Sakha (Yakutiya) } \\
\text { Sakhalin Oblast } \\
\text { Khabarovsk Territory }\end{array}$ & $\begin{array}{c}\text { Belgorod Oblast } \\
\text { Bryansk Oblast } \\
\text { Ivanovo Oblast } \\
\text { Kostroma Oblast } \\
\text { Kursk Oblast } \\
\text { Orel Oblast } \\
\text { Ryazan Oblast } \\
\text { Smolensk Oblast } \\
\text { Tambov Oblast } \\
\text { Tver Oblast } \\
\text { Tula Oblast } \\
\text { Yaroslavl Oblast } \\
\text { Arkhangelsk Oblast } \\
\text { Kaliningrad Oblast } \\
\text { Republic of Kareliya } \\
\text { Novgorod Oblast } \\
\text { Pskov Oblast } \\
\text { Respublika Adygeya } \\
\text { Astrakhan Oblast } \\
\text { Volgograd Oblast } \\
\text { Republic of Kalmykiya } \\
\text { Republic of Ingushetiya } \\
\text { Kabarda-Balkar Republic } \\
\text { Karachai-Cherkes Republic } \\
\text { Republic of North Ossetia - Alania } \\
\text { Stavropol Krai } \\
\text { Kirov Oblast } \\
\text { Republic of Mariy El } \\
\text { Republic of Mordoviya } \\
\text { Penza Oblast } \\
\text { Republic of Udmurtiya } \\
\text { Ulyanovsk Oblast } \\
\text { Republic of Chuvashia } \\
\text { Kurgan Oblast } \\
\text { Republic of Altay } \\
\text { Altai Krai } \\
\text { Republic of Buryatiya } \\
\text { Trans-Baikal Krai } \\
\text { Irkutsk Oblast } \\
\text { Tomsk Oblast } \\
\text { Republic of Tyva } \\
\text { Republic of Khakasiya } \\
\text { Amur Oblast } \\
\text { Jewish Autonomous Oblast }\end{array}$ \\
\hline
\end{tabular}

Tables 9 and 10 show that Moscow and Moscow Oblast are the absolute leaders by all parameters; these regions are included into the first group. The group is the smallest and includes only two regions. The second group includes slightly more regions - in 2010 it included 6 regions attractive for investors. Groups 3 and 4 are the most numerous and unattractive for economic activity, in 2010 group 4 (the most unattractive) was bigger that group 3 by 14 regions. Some regions of Russia, such as Krasnodar Krai, Republic of Bashkortostan and Sverdlovsk Oblast had improved their positions over 5 years, and moved from group 3 into group 2 thus having increased their attractive force. 
Tables 9 and 10 prove spatial differentiation of Russia's economy by means of spatial differentiation of factors affecting business location in regions. It is obvious that modern Russia has a very high level of spatial differentiation - most regions are the most unattractive for business location, and vice versa, only few regions are the most attractive for business location.

So, applying the neural networks to assess factors affecting the location of a business in Russian regions allows to identify regions with similar features in terms of basic factors of business location in conditions of incomplete information.

\section{Conclusions}

The results of the research are the following:

1. To investigate spatial differentiation of the regions' economic development, it is necessary to carry out analysis of regional economies based on numerous parameters affecting the attractiveness of a region for business location. In the context of incomplete information, applying self-learning neural networks gives good results. Neural networks, alternatively to the traditional methods of data processing operations, help to solve problems without preliminary hypotheses and theoretical conclusions (for example, to state that the desired value is linear or one variable has normal distribution). The neural approach can be used both for linear and complex nonlinear relations, but it is especially effective while used in the exploratory data analysis aiming at finding out any relations between different variables. It should be noted that the data can be incomplete, controversial or even knowingly corrupted. If there is relation between input and output data, even non-discoverable by the traditional correlation methods, the neural network is able to automatically set itself up for that relation with a desired level of accuracy.

2. The empirical analysis proved the hypothesis that Russia is characterized by a significant spatial differentiation of the market potential: only few Russian regions have the biggest market potential, whereas a large majority of the regions have small market potential. The obtained results emphasize spatial differentiation of Russia's economic development.

3. Segmentation of Russian regions based on the market potential and other multidimensional data allowed to group regions with similar features in terms of basic factors of business location. The obtained results prove the hypothesis about spatial differentiation of Russia's economy through spatial differentiation of factors of business location in Russian regions. Russia is characterized by a high and growing level of spatial differentiation: a large majority of the regions are the least attractive for business location and only few Russian regions are attractive for business location.

4. The results of Russia' regions segmentation allow to select the most attractive regions to locate a business. Thus, methods of "new economic geography" help to find patterns of business location in modern market economy of Russia.

5. Correlation-regression analysis helped to establish casual relationship between the fixed asset investment on the one hand and the number of economically active population and average nominal monthly wage on the other hand. However, there is no relationship between the fixed asset investment and retail market potential of a region.

6. The results of our research allow to determine the most important task of public authorities, both at the federal level and at the regional level, which is to reduce spatial differentiation of Russia's economic development. Normal economic development of the country is impossible in a situation where the capital and nearby regions are the only regions characterized by the maximum values.

7. The obtained results also allow to assess the effectiveness of the regional development policy and to find ways of increasing its effectiveness. To reduce the level of spatial differentiation it is proposed to take into account the specificity of certain groups of the regions, as well as to use the policy of selective impact on growth points in the regions, on key industries of economic growth. The transition of the regions from groups with low rates into groups with higher rates can indicate correct management decisions of public authorities in the sphere of economic policy.

\section{References}

Abramov, A., \& Gluschenko, K. (2000). The Shortest Distances between Capital Cities of Russian Regions (km). Novosibirsk, RF: Novosibirsk State University. Retrieved from http://econom.nsu.ru/staff/chair_et/ gluschenko/Research/Data/Distances.xls

Baldwin, R. E. (1998). Agglomeration and endogenous capital. NBER Working Paper, 6459. 
Baldwin, R., Forslid, R., Martin, P., Ottaviano, G., \& Robert-Nicound, F. (2003). Economic geography and public policy. Princeton, USA: Princeton University Press.

Dixit, A., \& Stiglitz, J. (1977). Monopolistic competition and optimum product diversity. American Economic Review, 67, 297-308.

Domar, E. D. (1946, April). Capital Expansion, Rate of Growth, and Employment. Econometrica, 14(2), 137-147. http://dx.doi.org/10.2307/1905364

Federal State Statistics Service. (2012). Central database of statistical information. Retrieved August 25, 2012, from http://www.gks.ru/dbscripts/Cbsd/DBInet.cgi

Fujita, M., Krugman, P., \& Venables, A. (1998). The spatial economy: cities, regions and international trade. Manuscript.

Harris, C. D. (1954). The market as a factor in the localization of industry in the United States. Annals of the Association of American Geographers, 44(4), 315-348.

Harrod, R. (1939). An Essay in Dynamic Theory. Economic Journal, 49, 14-33. http://dx.doi.org/10.2307/ 2225181

Haykin, S. (1999). Neural Networks: A Comprehensive Foundation (2nd ed.). New Jersey: Prentice-Hall.

Hebb, D. O. (1949). The organization of Behavior: A Neuropsychological Theory. New York: Wiley.

Hopfield, J. J. (1982, April). Neural networks and physical systems with emergent collective computational abilities. Proceedings of National Academy of Sciences, 79(8), 2554-2558. http://dx.doi.org/10.1073/pnas. 79.8.2554

Kohonen, T. (1982). Self-Organized Formation of Topologically Correct Feature Maps. Biological Cybernetics, 43, 59-69. http://dx.doi.org/10.1007/BF00337288

Kruglov, V. V., \& Borisov, V. V. (2001). Artificial Neural Networks. Theory and practice. Moscow: Hot line Telecom.

Krugman, P. (1991a). Geography and trade. Cambridge, MA: MIT Press.

Krugman, P. (1991b). History versus expectations. Quarterly Journal of Economics, 106(2), 651-667. http://dx.doi.org/10.2307/2937950

Krugman, P. (1991c). Increasing returns and economic geography. Journal of Political Economy, 99, 483-499. http://dx.doi.org/10.1086/261763

Krugman, P., \& Venables, A. (1995). Globalization and the inequality of nations. Quarterly Journal of Economics, 60, 857-880. http://dx.doi.org/10.2307/2946642

Krugman, P., \& Venables, A. (1996). Integration, specialization, and adjustment. European Economics Review, 40, 959-967. http://dx.doi.org/10.1016/0014-2921(95)00104-2

Lysenko, Y. G., Mints, A. Y., \& Stasyuk, V. G. (2002). A search for effective solutions to economic problems. Donetsk: Donetsk National University, Yugo-Vostok, Ltd.

Markusen, J. R., \& Venables, A. J. (1997). Foreign direct investment as a catalyst for industrial development. NBER Working Paper, 6241.

Martin, P., \& Ottaviano, G. I. (1996). Growth and agglomeration. Center for Economic Policy Research (CEPR), Discussion Paper, 1529.

Martin, P., \& Ottaviano, G. I. (1999). Growing location: Industry location in a model of endogenous growth. European Economics Review, 43, 281-302. http://dx.doi.org/10.1016/S0014-2921(98)00031-2

Matsuyama, K. (1991). Increasing returns, Industrialization and indeterminacy of equilibrium. Quarterly Journal of Economics, 106(2), 617-650. http://dx.doi.org/10.2307/2937949

McCulloch, W. S., \& Pitts, W. (1943). A logical calculus of the ideas immanent in nervous activity. Bulletin of Mathematical Biophysics, 5, 115-133. http://dx.doi.org/10.1007/BF02478259

Minsky, M. L., \& Papert, S. A. (1969). Perceptions. Cambridge, MA: MIT Press.

Odrin, V. M., \& Kartavov, S. S. (1977). Morphological analysis of systems. Kiev, Ukraine: Naukova Dumka.

Puga, D. (1999). The rise and fall of regional inequalities. European Economics Review, 43(2), 303-334. http://dx.doi.org/10.1016/S0014-2921(98)00061-0 
Rosenblatt, F. (1958). The perceptron: A probabilistic model for information storage and organization in the brain. Psychological Review, 65, 386-407. http://dx.doi.org/10.1037/h0042519

Rumelhart, D. E., Hinton, G. E., \& Williams R. J. (1986). Learning internal representations by error propagation. In J. L. McClelland, \& D. E. Rumelhart (Eds.), Parallel Distributed Processing: Explorations in the Microstructure of Cognition (Vol. 1, pp. 318-362). Cambridge MA: MIT Press.

Russia-2012. Statistical Handbook, 2012 (pp. 33-34). Moscow, RF: Rosstat.

Venables, A. (1996). Equilibrium location with vertically linked industries. International Economics Review, 37, 341-359. http://dx.doi.org/10.2307/2527327

\section{Copyrights}

Copyright for this article is retained by the author(s), with first publication rights granted to the journal.

This is an open-access article distributed under the terms and conditions of the Creative Commons Attribution license (http://creativecommons.org/licenses/by/3.0/). 